Case Study

\title{
Surgical Management of Cutaneous Haemangioma in a Non-Descript Dog: A Case Report
}

\author{
Jignesh Parmar ${ }^{1 *}$, Prashant Dabhi ${ }^{2}$, Angel Parmar ${ }^{1}$, Kavita Kurup ${ }^{1}$ and Pinesh Parikh ${ }^{1}$ \\ ${ }^{1}$ Department of Veterinary Clinical Complex, ${ }^{2}$ Department of Veterinary Surgery and \\ Radiology, C. V. Sc. \& A. H., Anand, Gujarat, India \\ *Corresponding author
}

\section{A B S T R A C T}

\section{Keywords \\ Haemangioma, Non- descript dog, Surgical management \\ Article Info \\ Accepted: \\ 10 August 2018 Available Online: \\ 10 September 2018}

A one year non- descript female dog was presented with history of bleeding from red colour mass at right side lower flank which enlarge since two months. Under general anaesthesia surgical excision was done and dog recovered uneventfully without any complication. Histopathology of excised mass revealed cutaneous haemangioma.

\section{Introduction}

A cutaneous haemangioma is a benign neoplasm found on the skin of dogs. It can originate either in the dermis or the subcutaneous layer of the skin as a result of a mutated cell or cells that line a blood vessel. Haemangiomas are benign tumours of vascular endothelial cells which common in dogs and rare in other species. In dogs cutaneous haemangiomas are common as compare to hemangiosarcoma and mostly occur in younger dogs (Lather et al., 2015). Haemangiomas are benign and usually solitary masses in the dermis or subcutis (Kim et al., 2005). This case report described case of subcutaneous haemangioma in nondescript dog.

\section{Case history and examination}

One year old non-descript female dog was presented with history of bleeding from red coloured mass at right side lower flank abdominal wall since two and half month appeared as a small growth which enlarges and started bleeding.

Clinical examination revealed dog was healthy and all the physiological parameters within normal range. Clinical palpation of tumour mass revealed small granulomatous growth originated from subcutaneous tissues which has tendency to bleed and no other skin lesions or growth was noted on body. The surgical excision was planned to remove growth. 


\section{Treatment and Discussion}

Surgical excision was done following surgical protocols and under general anaesthesia mass was removed which appeared small, red and soft in consistency. Post operatively dog was given Inj. Ceftriaxone and Tazobactam @ 15 $\mathrm{mg} / \mathrm{kg}$ and Inj.

Meloxicam @ $0.1 \mathrm{mg} / \mathrm{kg}$ along with antiseptic dressing. Skin suture removed after 12 days and dog was recovered uneventfully. Histopathological examination of resected mass revealed cutaneous haemangioma.

Skin of dogs is most commonly affected organ for neoplastic and non-neoplastic tumours. Haemangioma is a benign tumour of vascular endothelial tissue that occur in variety of sites viz. skin, liver, spleen, kidney, bone, tongue and heart (Sawale et al., 2014).

In dogs generally solar radiation is a contributing factor in the development of several skin neoplasms including haemangiomas and hemangiosarcomas (Gross et al., 2005).

Barber et al., (2012) reported histologically the hemangioma was appearing well circumscribed masses composed of discrete vascular structure lined by single layer of flattened endothelial cells arranged on fine collagenous septa and filled by erythrocytes which is similar to our histological findings.

Lather et al., (2015) reported haemangioma on left flank abdominal region while Kim et al., (2005) reported on right dorsal antebrachium and on the right shoulder in mixed breed spayed female which removed surgically while Balachandran et al., (2014) reported cavernous haemangioma in three year old Rajpalatyam dog at chest region and removed surgically. In our case tumour was arise from cutaneous tissue of right side lower flank area in a non-descript young female dog and treated surgically.

\section{Acknowledgement}

The authors are thankful to the Dean, Veterinary College, Anand for providing necessary facilities at Department.

\section{References}

Balachandran, C., Pazhanivel, N., Baranidharan, G. R., Jalantha, P. and Sridhar, R. 2014. Cavernous Haemangioma in a Dog. Indian J. Anim. Res., 48(3): 303-304.

Barber, K. A., newkirl, K. M., Reed, A. and Donnel, R. L. (2012). Evaluation of mast cell in dermal versus subcutaneous Hemangiomas and Hemangiosarcoma in dogs. Open Journal of Veterinary Medicine, 2: 60-65.

Gross, T.L., Ihrke, J.P. and Walder, E.J. 2005. Neoplasms and Other Tumors. In: Skin Diseases of the Dog and Cat: Clinical and Histopathologic Diagnosis. 2nd edn., Blackwell Science, UK. PP: 735753.

Kim, Y. Reinecke, S. and Malarkey, D. E. 2005. Cuteneous angiometosis in a Young Dog. Vet Pathology, 42:378381.

Lather, D. Nehra, V. Gupta, R. P. and Jakhar, K. K. 2015. Cutaneous Haemangioma in a Dog- Case Report. Haryana Vet, 54(1):89-90.

Sawale, G. K., Dave, V. N., Satpute, A., Savla, Y. S., Rohi, R., Gavhane, D. S., Mhase, A. K. and Moregaonkar, S. D. 2014. Occurrence of Cavernous Haemangioma in Labrador Dog: a case report. Indian Journal of Canine Practice, 6(2): 177-178. 


\section{How to cite this article:}

Jignesh Parmar, Prashant Dabhi, Angel Parmar, Kavita Kurup and Pinesh Parikh. 2018. Surgical Management of Cutaneous Haemangioma in a Non-Descript Dog: A Case Report. Int.J.Curr.Microbiol.App.Sci. 7(09): 1627-1629. doi: https://doi.org/10.20546/ijcmas.2018.709.195 